\title{
Linguistic markers of represented speech in science fiction novels: a polyphonic approach ${ }^{1}$
}

This paper aims to investigate the linguistic aspect of represented speech in the novel "The Martian Chronicles" by Ray Bradbury within the framework of M. Bakhtin's concept of polyphony. The article provides a classification of linguistic signals of voices, determines their frequency, types of represented speech, the number of voices. The results of the study show that fragments with represented speech in the novel are few; as a rule, there are two voices in them. In other passages, despite the presence of several voices, the dialogical perspective is not expressed. Moreover, one linguistic marker can be simultaneously a lexical, syntactic and graphic signal; ideological markers creating a slight polyphonic effect. Syntactic means, being the most frequent ones, convey the perception of the character and form Bradbury's special narration style.

Keywords: represented speech, polyphony, voices, linguistic markers.

\begin{abstract}
Изучен языковой аспект несобственно-прямой речи в романе «Марсианские хроники» Рэя Брэдбери в рамках концепции полифонии М. Бахтина. Приведена классификация лингвистических сигналов голосов, определена их частотность, типы несобственно-прямой речи, количество голосов. Результаты исследования показывают, что фрагменты с несобственно-прямой речью в романе немногочисленны и состоят, как правило, из двух голосов. В других отрывках, несмотря на присутствие нескольких голосов, не выражена диалогическая перспектива. Отмечено, что один лингвистический маркер может быть одновременно лексическим, синтаксическим и графическим сигналом; идеологические маркеры создают легкий полифонический эффект. Синтаксические средства, являясь самыми частотными, передают восприятие персонажа и формируют особый стиль письма Р. Брэдбери.
\end{abstract}

Ключевые слова: несобственно-прямая речь, полифония, голоса, лингвистические маркеры.

\section{Introduction}

The term "polyphony" primarily referred to music was first used for literary studies by M. Bakhtin in his "Problems of Dostoevsky's Poetics". Polyphony literally means presence of many consciousnesses or voices in the text existing in their worlds [2. P. 6]. Characters declare their points of view openly, make judgments that often contradict the author's opinion. As a result, constant interplay of various ideologies belonging to different people arises. This phenomenon was a popular object of study among linguists and literary scientists of the twentieth century [10;12].

Polyphony in literary texts is mostly achieved by means of the "narrated consciousness" technique [8. P. 97-112]; other terms for it are "free indirect speech" [11] or "represented speech" [4]. Represented speech (RS) ordinarily means transmission of thoughts, feelings, utterances embedded in the 3rd person narration; a person's manner of speaking, his beliefs being preserved.

RS can be quite emotional and philosophical compared with the narrator's monotonously repeated introductory remarks. RS can be expressed by means of the inner dialogue or monologue [1; 5; 6; 9]. In case of the internal dialogue consciousness splits in two parts which enables a person to communicate to himself (herself). RS may be verbal (conversations) and nonverbal (ideas).

Polyphony is widespread in all areas of life and is not restricted to literature or music only, since our speech is overfilled with snatches of conversations summed up with highly varied degrees of accuracy and impartiality [3. P. 259-422]. Any kind of language, as well as any literary work can be polyphonic. Almost all novels contain dialogues and views, but what makes them really polyphonic is the dialog angle at which the voices debate or agree with one another [10. P. 49-51].

This paper aims to investigate a science fiction text applying a polyphonic approach what accounts for its scientific novelty, the principle hypothesis being that the novel under discussion may be polyphonic.

\footnotetext{
${ }^{1}$ Демина Е.А. Лингвистические маркеры несобственно-прямой речи в научно-фантастическом романе: полифонический подход.
} 
The tasks of our research include description, classification and estimation of various linguistic devices employed as markers of voices. Its topicality is determined by the fact that science fiction texts are important for real life, since they are full of predictions which may lead to great discoveries in future. Due to this reason, the linguistic aspect of these texts should be the object of close study.

\section{Materials and methods}

Forty pages of “The Martian Chronicles" by Bradbury were analyzed, six extracts selected. During research we applied the method of linguistic observation, the continuous sampling and quantitative method. The text analysis model includes such aspects as: structural type of the unit (pronounced words vs thoughts); linguistic markers. To avoid repetition of the same information we will further refer to the original text using abbreviations for the corresponding linguistic means: L. for lexical, G. for grammar, S. for syntactic; Graph. for graphic; Id. for ideological ones; number of voices in a passage. We will also use brackets and numbers while indicating and counting linguistic signals in the fragment: i. e. (rushing: G.1) = "rushing" is the first grammar marker.

Let us turn to analysis of Extract 1:

(Rocket summer: L.1; S.1; Graph.1). The words passed among the people in the open air, (airing: G.1) houses. (Rocket summer: L.1; S.2; Graph.2). (The warm desert air (changing: G.2) the frost patterns on the windows, (erasing: G.3) the art work: S.4). (The skis and sleds suddenly useless: S.5). (The snow, (falling: G.4) from the cold sky upon the town, turned to a hot rain: L.2) before it touched the ground. (Rocket summer. L.1; S.3; Graph.3). People leaned from their (dripping: G.5) porches and watched the (reddening: G.6) sky [7. P. 11].

A dramatic metamorphosis in routine life of one American town was provoked by the spaceship sent to Mars; as a result it got very warm in winter suddenly. The phrase "Rocket summer" embedded into the narrator's description can be classified as verbal RS (actually pronounced words). Lexical markers include two metaphors (L.1, L.2). Grammar means comprise the repeated use of Participle I by the narrator (G.1, G.2, G.3, G.4, G.5, G.6) that slows down time in the passage to create a close-up and emphasize the uniqueness of the moment. There are also syntactic means: repetition (S.1-S.3); ellipsis expressing the author's surprise (absence of predicates in the sentences: S.4, S.5). The author italicizes the unanimous opinion of the inhabitants three times (graphic markers: Graph 1-3). Thus, one unit of the fragment ("Rocket summer") obtains three linguistic features: lexical (metaphor), syntactic (repetition) and graphic (italics) ones. It becomes a key phrase of the extract helping us to identify the voice of the astonished crowd. Due to the linguistic markers described above we can also "hear" the narrator's voice who describes the shocking scene and also seems bewildered. This passage demonstrates presence of many voices (the inhabitants + the narrator); all of them being equally surprised.

In Extract 2 we may observe the dominating voice of the narrator and the character's timid reflections:

Tired of waiting, she walked through the (misting: G.1) pillars. A gentle rain sprang from the fluted pillartops, (cooling: G.2) the scorched air, (falling: G.3) gently on her. On hot days (it was like walking in a creek: L.1). The floors of the house glittered with cool streams. In the distance she heard her husband (playing: G.4) his book steadily, his fingers never tired of the old songs. Quietly she wished (he: G.8) might one day again spend as much time ((holding: G.5) and (touching: G.6) her like a little harp: L.2) as (he: G.8) did his (incredible books: L.3).

(But no.: S.1). She shook her head, an imperceptible, (forgiving: G.7) shrug. Her eyelids closed softly down upon her golden eyes. (Marriage made people old and familiar, (while still young: S.2): Id.1) [7. P. 12].

The passage under analysis can be referred to the non-verbal type of RS. The action takes place in a Martian family consisting of a husband and wife. In fact, here we deal with Ylla's thoughts, her secret 
desires, her disappointment, the omniscient narrator's phrase “Quietly she wished” being a proof of it. Lexical markers include two comparisons pointing out the character's voice (L1, L2), an epithet (L.3). Grammar means embrace Participle I which signals both the narrator's voice (G.1, G.2, G.3, G.7) and Ylla's one (G.4, G.5, G.6) making another "close -up" of the scene; the use of the 3rd person singular pronoun by Ylla in relation to her husband (G.8). Syntactic markers of the character's speech are: elliptical constructions (S.1, S.2). It's worth mentioning that the last sentence sounds like a copy book maxim, a belief that most people from Earth would also share in real life. We call it "an ideological marker" of RS because it expresses, so to say, opinion of many married people, not only Ylla's point of view. We can't but sympathize with Ylla's loneliness and disappointment in marriage expressed in the last sentence. We understand that on Mars people may be unhappy too. So here we again deal with plurality of consciousnesses, each within its own world (the narrator, Ylla, people in general). However, there is no dialogue, no argument, that is why it's hard to call this extract truly polyphonic.

Extract 5 presents a mixture of RS and indirect speech:

He wanted (to go to Mars: S.1) on the rocket. He went down to the rocket field in the early morning and yelled in through wire fence at the men in uniform that he wanted (to go to Mars: S.2). He told them he was a taxpayer, his name was Pritchard, and he had a right (to go to Mars: S.3). (Wasn't he born right here in Ohio? S.12). (Wasn't he a good citizen? S.13). Then why couldn't he (go to Mars: S.4)? He shook his fists at them and told them that he wanted to get away from Earth; anybody with any sense wanted to get away from Earth. There was going to be a big atomic war on Earth in about two years, and he didn't want to be here when it happened. ((He and thousands of others like him: L.1), if they had any sense, would (go to Mars: S.5): Id.1). (See if they wouldn't! G.2; S.16; S.20). (To get away from wars and censorship and statism and conscription and government control of this and that, of art and science! S.17; S.21; S.22; Id.2). ((You: G.1; S.8) could have Earth! S.18). ((He was offering his good right hand, his heart, his head: G.3) for the opportunity (to go to Mars: S.6)! S.19)). (What did (you: G.1; S.9) have to do, what did (you: G.1; S.10) have to sign, whom did (you: G.1; S.11) have to know, to get on the rocket? S.15) They laughed out through the wire screen at him. He didn't want (to go to Mars: S.7), they said (Didn't he know that the First and Second Expeditions had failed, had vanished; the men were probably dead? S.14) [7. P. 31].

As for the type of speech, we deal here with pronounced RS in the 3rd person singular which shifts to the 2nd person. As to lexical means, we should mention a comparison (L.1) used by Pritchard in relation to other Earth men. Grammar markers of Pritchard's voice indicate his anxiety and longing to leave the planet: the personal pronoun "you" used generally (G.1); the imperative mood (G.2); the atypical use of the Past Continuous with the verb "to offer" (G.3). The passage abounds in syntactic markers. The phrase "to go to Mars" is repeated 7 times(!) becoming the key phrase of the extract (S.1-S.7); the pronoun "you" is used 4 times (S.8-S.11). General questions in the form of parallel constructions with negation are of special interest (S.12-S.14). Questions of the kind are the markers of the character's voice because they are not transformed into indirect speech according to the rules. They are written separately without the narrator's introductory clause; the negative particles and question marks preserved. There are also three syntactically parallel special questions in one sentence accompanied by the repetition of the verb "to have" and pronoun "you" (S.15). There are four exclamatory sentences following one another (S.16-S.19). The first sentence is both exclamatory and elliptical (S.20). The second sentence is also elliptical (S.21): it has neither subject nor predicate and starts with the infinitive, then comes the chain of nouns connected by polysyndeton (S.22). Thus, from the syntactic point of view we deal in one sentence with three markers: ellipsis, exclamation and polysyndeton (S.17; S.21; S.22) which makes this sentence sound very emotional. The unanimous urge of the crowd to leave the planet is expressed by Pritchard in the same sentence (Id.1); we may call it an ideological marker. Pritchard then explains his pacifist ideology and gives the reason why he and others want to leave 
the planet (Id.2). In the last sentence of the passage we can hear the voices of several men in the uniform which enables us to identify the whole passage as polyphonic (the narrator + Pritchard + those willing to go to Mars + the men in the uniform). There is a dialogue, a heated discussion of a vital issue, but no agreement is achieved.

\section{Results}

The results of the research are given in Table. They demonstrate that in six selected extracts syntactic and grammar markers are the most common ones, ideological and graphic markers are the least common. Represented speech is not wide spread in the material under research; it may be both pronounced (2 extracts) and non-verbal (4 extracts). As to the number of voices, there are two voices in three extracts and more than two voices in three extracts.

Linguistic Markers of RS

\begin{tabular}{|l|l|c|c|c|c|c|c|}
\hline $\begin{array}{c}\text { Number } \\
\text { of extract }\end{array}$ & \multicolumn{1}{|c|}{$\begin{array}{c}\text { Structural type of the } \\
\text { character's speech }\end{array}$} & $\begin{array}{c}\text { Lexical } \\
\text { markers }\end{array}$ & $\begin{array}{c}\text { Grammar } \\
\text { markers }\end{array}$ & $\begin{array}{c}\text { Syntactic } \\
\text { markers }\end{array}$ & $\begin{array}{c}\text { Graphic } \\
\text { markers }\end{array}$ & $\begin{array}{c}\text { Ideological } \\
\text { markers }\end{array}$ & $\begin{array}{c}\text { Number } \\
\text { of voices } \\
\text { identifiable }\end{array}$ \\
\hline 1 & Pronounced speech & 2 & 6 & 5 & 3 & & $>2$ \\
\hline 2 & Non verbal speech & 3 & 7 & 2 & & 1 & $>2$ \\
\hline 3 & Non verbal speech & 4 & 1 & 9 & & & 2 \\
\hline 4 & Non verbal speech & 1 & 4 & 6 & & & 2 \\
\hline 5 & Pronounced speech & 1 & 3 & 22 & & 2 & $>2$ \\
\hline 6 & Non verbal speech & 9 & 5 & 26 & 1 & & 2 \\
\hline Total & & 20 & 26 & 70 & 4 & 3 & \\
\hline
\end{tabular}

\section{Discussion}

It is hard to explain high frequency of syntactic means in the extracts analyzed, yet one may attribute it to Bradbury's specific manner of depicting the inner world of his characters and their emotions. Such syntactic means as questions, ellipsis, repetition and exclamations help the author express characters emotions (excitement, fright). More detailed and thorough examination is necessary to detect other cases of polyphony in science fiction novels. Possible prospects of study are numerous, they could include closer analysis of ideological markers and their classification, specific use of tense forms as grammar markers of voices, as well as analysis of linguistic markers of the narrator's voice. The major problem we faced in the research is difficulty in differentiating the narrator's voice from that of a character.

\section{Conclusion}

From the six fragments only Extract 5 meets polyphonic criteria best of all: there are many voices arguing with one another. We may also find some specific kind of partial polyphony produced, primarily, by the presence of many voices (Extract 1,2), not by the dialogue maintained by them. This effect can be achieved with the help of ideological markers revealing people's views on something. Ideological markers are able "to connect" readers to the collective mind making them match their own system of values with those of the characters'. The most peculiar feature of accentuating voices is a combination of lexical, syntactic and graphic characteristics in one marker which makes the signal very emotional.

Thus, we should note that polyphony in the material under research is a rare phenomenon bounded by a single fragment. However, cases of represented speech with various linguistic markers of voices have been found in the novel. 


\section{References}

1. Bajdikova N.L. Formal'no-stilisticheskie kharakteristiki sposobov peredachi chuzhoi rechi (na materiale angloiazychnykh khudozhestvennykh proizvedenii) $=$ [Formal and stylistic characteristics of discourse representation modes in English fiction] $/ /$ Nauchnyi dialog $=$ [Scientific Dialog]. Ekaterinburg, 2018. No. 3. P. 19-31. (In Russian).

2. Bakhtin M.M. Problems of Dostoevsky's poetics. Theory and history of literature. University of Minnesota press, 2013 . Vol. 8 . 384 p. URL: https://books.google.ru/books?id=MkXAzSbkU8QC\&pg=PA6\&lpg=PP1\&focus=viewport\&hl=ru\&output=html_text/ $\mathrm{d}(20.09 .2019)$.

3. Bakhtin M.M. The dialogic imagination: four essays / M. Holquist (ed.). University of Texas Press, 2010.480 p.

4. Banfield A. Narrative style and the grammar of direct and indirect speech // Foundations of Language. 1973. Series 10. No. 1. P. 1-39.

5. Blinova O.A. Nesobstvenno-pryamaya rech' ili vnutrennij monolog: $\mathrm{k}$ probleme razgranicheniya $=[$ Free indirect speech or internal monologue: on problem of differentiation] // Filologicheskie nauki. Voprosy teorii i praktiki = [Philological Sciences: Issues on Theory and Practice]. 2015. No. 2, part 1. P. 37-40. (In Russian).

6. Blinova O.A. Nesobstvenno-priamaia rech v angliiskom iazyke: evolutsia vzgliadov v zapadnoi lingvistike $(1912-2012)=[$ Free indirect discourse in English: evolution of Theories in European and American linguistics (1912-2012)] // Vestnik Novosibirskogo gosudarstvennogo universiteta. Lingvistika i mezhkul'turnaia kommunikatsiia = [The Herald of Novosibirsk State University. Linguistics and Cross-Cultural Communication]. 2012. Series 10. No. 2. P. 93-102. (In Russian).

7. Bradbury R. The Martian chronicles. London: Harper Collins Publishers, 1995. 320 p.

8. Cohn D. Narrated monologue: definition of a fictional style // Comparative Literature. 1966. Vol. 18, no. 2. P. 97-112.

9. Lyubimova E.A. Izobrazhennaia vnutrenniaia rech' sviashhennosluzhitelia v strukture romana Grema Grina "Sila i Slava" $=[$ Priest's represented inner speech in the structure of G. Greene's novel "The Power And The Glory"] // Filologicheskie nauki. Voprosy teorii i praktiki $=[$ Philological Sciences: Issues on Theory and Practice]. 2018. No. 8. P. 120-125.

10. Masayuki T. Polyphony in fiction: a stylistic analysis of Middlemarch, Nostromo, and Herzog / Peter Lang (ed.). Bern, 2008. 328 p.

11. Pascal $R$. The dual voice. Free indirect speech and its functioning in the 19th century. Manchester University Press, 1977. $150 \mathrm{p}$.

12. Robinson A. In theory Bakhtin: dialogism, polyphony and heteroglossia // Ceasefire. 2011. URL: https://ceasefiremagazine. co.uk/in-theory-bakhtin-1/ (30.10.2019).

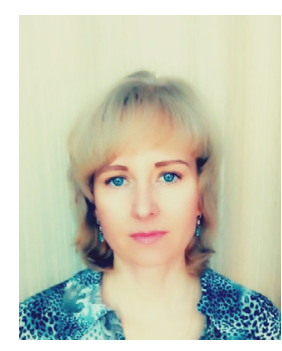

Demina Elena Anatolyevna,

Candidate of Philology, Associate Professor

of the Foreign Languages with a Course of Latin Department

Altai State Medical University

e-mail: demelena7@mail.ru

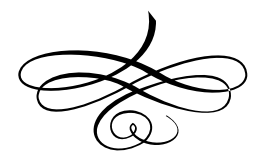

